Stream, and having no harbor that vessels drawing more than seven feet of water can enter. We stopped here to meet $\mathrm{Mr}$. Charles Washburn, one of my collectors, who had been staying on the Islands for about three weeks. Very few resident species were obtained, but it is more than probable that a number of Bahama forms occur there which were not observed by us, as the time spent on these Islands was much too short to make anything like a thorough investigation.

Sterna maxima Bodd.

Pelecanus fuscus Linn.

Fregata aquila (Linn.).

Ardea herodias Linn.

Ardea virescens bahamensis

(Brezuster).

Agialitis vocifera (Linn.).

Columbigallina passerina (Linn.).

Columba leucocephala Linn.

Crotophaga ani Linn.

Ceryle alcyon (Linu.).

Sphrrapicus varius (Linn.).

Doricha evelynæ (Bourc.).

Tyrannus dominicensis ( $\mathrm{Gmcl}$ ).

Agelaius phœniceus bryanti Ridgzw.

Euetheia bicolor (Linn.).

Ammodramus savannarum passerinus (Wils.).
Vireo crassirostris Bryant.

Vireo altiloquus barbatulus ( $C a b$.).

Cœreba bahamensis (Keich.).

Mniotilta varia (Linn.).

Helinaia swainsoni Aud.

Compsothlypis americana ( $\operatorname{Linn}$.).

Dendroica tigrina (Gmel.).

Dendroica coronata (Linn.).

Dendroica dominica (Linn.).

Dendroica palmarum (Gmel.).

Dendroica discolor (Vieill.).

Geothlypis trichas (Linn.).

Setophaga ruticilla (Linn.).

Seiurus motacilla (Vieill.).

Seiurus aurocapillus ( $\operatorname{Linn}$.).

Polioptila cærulea (Linn.).

Galeoscoptes carolinensis (Linn.).

Mimus polyglottos orpheus (Linn.).

\title{
LIST OF THE BIRDS COLLECTED BY C. L. WINCH IN THE CAICOS ISLANDS AND INAGUA, BA- H IMAS, DURING JANUARY AND FEBRUARY, AND IN ABACO, IN MARCH, ISgI.
}

BY CHARLES B. CORY.

Caicos Islands.

Dafila bahamensis (Linn.). - Not uncommon; breeds on the Caicos Islands.

Aythya affinis (Eyton).

Ardea rufescens Bodd.-Several specimens of both the white and col ored plumage of this species. 
Ardea tricolor ruficollis (Gosse).

Symphemia semipalmata (Gmel.).

Hæmatopus palliatus ( Temm).

Columbigallina passerina ( i iln $)$.

Columba leucocephala Linn.

Zenaida zenaida ( Limu.).

Pandion haliaëtus carolinensis (Gmel.).

Coccyzus minor maynardi Ridgw.

Crotophaga ani Linn.

Sphyrapicus varius (Limn.).

Doricha evelynæ (Bourr.).

Tyrannus magnirostris D'Orb.-Three specimens taken. It has not previously been recorded north of Inagua.

Loxigilla violacea (Linn.).

Euetheia bicolor (Linn.).

Vireo crassirostris (Bryant).

Coreba bahamensis (Reich.).

Compsothlypis americana (Linn.).

Dendroica petechia gundlachi Baird.

Dendroica coronata (Linn.).

Dendroica kirtlan di Baird-Two specimens taken. I believe it has no previous record so far south. The naturalists of the 'Albatros' expedition found it not uncommon in Rum Cay.

Dendroica palmarum (Gmel.).

Dendroica discolor (Vieill.).

Seiurus aurocapillus (Linn.).

Polioptila cærulea ( $\operatorname{Lin} n$.).

Mimus gundlachi $C a b$.

Margarops fuscatus (Vieill.).

INAGUA.

Ardea herodias Linn.

Sphyrapicus varius (Linn.).

Doricha lyrura Gould.

Tyrannus magnirostris $D^{\prime}$ Orb.

Myiarchus sagræ Gundl.

Loxigilla violacea (Limn.). - Mr. Winch writes me he believes the adult female of this species assumes a black plumage similar to the male. A number of black specimens taken by him proved on dissection to be females.

Euetheia bicolor (Linn.).

Vireo crassirostris (Bryant).

Cœreba bahamensis (Reich.).-Birds from Inagua have larger bills than those which occur on the northern Bahama Islands.

Dendroica tigrina (Gmel.).

Dendroica petechia gundlachi Baird.

Dendroica coronata (I inn.). 
Dendroica dominica ( imn.).

Dendroica discolor (Vieill.).

Seiurus aurocapillus (Linn.).

Polioptila cærulea ( $\operatorname{Linn}$.) .

Mimus gundlachi $\mathrm{Cab}$.

Mimus polyglottos elegans (Sharpe). - Since writing the paper on Mimus polyglotios and $M$. orpheus which appeared in the January 'Auk' (p. 45) I have received some fifty specimens of the small Mimus from Inagua. With this additional material for comparison $I$ find that a large majority of the Inagua specimens are somewhat smaller than orpheus or polyglottos and have the primary coverts nearly and often completely covering the white on the quills. These differences are not constant but are probably sufficient to justify subspecific separation.

Margarops fuscatus (Vieill.).

A box of birds lately received from Inagua contained two species not observed by Mr. Winch. These are :-

Dendroica striata (Forst.). - Six specimens, April 23 to May 2.

Dendroica cærulescens (Gmel.). - Nine specimens, April 22 to May I.

Aв ACO,

Egialitis semipalmata Bonaf.

Columbigallina passerina ( $\operatorname{Linn}$.).

Cathartes aura ( $\operatorname{Linn}$.).

Crotophaga ani Linn.

Ceryle alcyon (Linn.).

Dryobates villosus maynardi Ridgzv.

Doricha evelynæ (Bourc.).

Sporadinus ricordi (Gerv.).

Myiarchus sagræ Gundl.

Pitangus bahamensis Bryant.

Loxigilla violacea ( $\operatorname{Linn}$.).

Euetheia bicolor (Linn.).

Spindalis zena townsendi Ridgw.

Vireo crassirostris (Bryant).

Vireo altiloquus barbatulus ( $C a b$.).
Coreba bahamensis (Reich).

Mniotilta varia ( $\operatorname{Linn}$.).

Dendroica kirtlandi Baird.

Dendroica petechia gundlachi Baird.

Dendroica discolor (Vieill.).

Dendroica coronata ( $\operatorname{Linn}$.).

Dendroica dominica (Linu.).

Geothlypis trichas ( $\operatorname{Linn}$.).

Geothlypis tanneri Ridgw.

Seiurus noveboracensis (Gmel.).

Seiurus aurocapillus (Linn.).

Polioptila cærulea Linn.

Galeoscoptes carolinensis (Linn.). Mimus polyglottos orpheus (L.). Mimocichla plumbea ( $\operatorname{Linn}$ ). 


\section{$2 \mathrm{BHL}$ Biodiversity Heritage Library}

Cory, Charles B. 1891. "List of the Birds Collected by C. L. Winch in the Caicos Islands and Inagua, Bahamas, during January and February, and in Abaco, in March, 1891." The Auk 8, 296-298. https://doi.org/10.2307/4067859.

View This Item Online: https://www.biodiversitylibrary.org/item/55098

DOI: https://doi.org/10.2307/4067859

Permalink: https://www.biodiversitylibrary.org/partpdf/88389

\section{Holding Institution}

Smithsonian Libraries

\section{Sponsored by}

Smithsonian

\section{Copyright \& Reuse}

Copyright Status: Public domain. The BHL considers that this work is no longer under copyright protection.

This document was created from content at the Biodiversity Heritage Library, the world's largest open access digital library for biodiversity literature and archives. Visit BHL at https://www.biodiversitylibrary.org. 